\title{
Postawy przedsiębiorcze studentów wybranych uczelni Lubelszczyzny a rozwój przedsiębiorczości akademickiej
}

\author{
Monika Jakubiak*, Krystyna Buchta**
}

Postepujaca globalizacja, zmiany społeczne i technologiczne implikuja konieczność wspótpracy nauki z biznesem. Aktualnie szkoty wyższe nie realizuja tylko dotychczasowych zadań zwiazanymi z rozwojem jednostek $i$ zdobywaniem przez nie wiedzy. Staja się coraz częściej instytucjami ułatwiającymi przejście studentów z etapu nauki do pracy zawodowej. W szczególności wzrastać powinno zaangażowanie uczelni $w$ ksztatcenie $i$ wspieranie postaw przedsiębiorczych studentów. Ten element procesu ksztatcenia staje się bowiem coraz istotniejszy nie tylko z perspektywy rozwoju karier absolwentów, ale także innowacyjności poszczególnych regionów. W prezentowanym opracowaniu podjęta została problematyka przedsiębiorczości akademickiej, mierzonej aktywnościa studentów w podejmowaniu działalności gospodarczej. Celem autorek była identyfikacja czynników determinujących postawy przedsiębiorcze badanych studentów. Materiat empiryczny uzyskano za pomoca metody sondażu diagnostycznego z technika ankiety przeprowadzonej wśród 390 studentów drugiego stopnia kształcenia w publicznych szkołach wyższych Lubelszczyzny, realizujacych ksztatcenie w obszarach inteligentnych specjalizacji.

Słowa kluczowe: edukacja przedsiębiorcza, przedsiębiorczość akademicka, inteligentne specjalizacje.

Nadesłany: 20.06.2015 | Zaakceptowany do druku: 28.09.2015

\section{Entrepreneurial Attitudes of Students from the Selected Lublin Universities vs the Development of Academic Entrepreneurship}

Globalisation, social and technological changes necessitate science-business cooperation. At present, apart from fostering development and acquisition of knowledge, modern universities are becoming institutions which facilitate students' transition from learning to professional careers. Universities have become involved in the development of students' entrepreneurial attitudes. This element has gained in significance not only due to its influence upon the graduates' careers but also from the point of view of innovation in individual regions. The present paper tackles the issue of academic entrepreneurship, which is measured by students' activity

\footnotetext{
* Dr Monika Jakubiak, Uniwersytet Marii Curie-Skłodowskiej, Wydział Ekonomiczny, Instytut Zarządzania, Zakład Zarządzania.

Adres do korespondencji: Uniwersytet Marii Curie-Skłodowskiej, Wydział Ekonomiczny, Instytut Zarządzania, Zakład Zarządzania, Pl. M. Curie-Skłodowskiej 5, 20-031 Lublin; e-mail: monika.jakubiak@umcs.pl.

** Dr Krystyna Buchta, Akademia Wychowania Fizycznego Józefa Piłsudskiego w Warszawie, Filia w Białej Podlaskiej, Zakład Marketingu i Statystyki.

Adres do korespondencji: Akademia Wychowania Fizycznego Józefa Piłsudskiego w Warszawie, Filia w Białej Podlaskiej, Zakład Marketingu i Statystyki, ul. Akademicka 2, 21-500 Biała Podlaska.
} 
in undertaking business operation. The objective of the paper was to identify factors determining students' entrepreneurial attitudes. Empirical data was collected by means of a questionnaire in a diagnostic survey conducted among 390 graduate students of public universities in Lublin region which offer education in the fields covered by intelligent specialisations.

Keywords: entrepreneurial education, academic entrepreneurship, intelligent specialisations.

Submitted: 20.06.2015 | Accepted: 28.09.2015

JEL: O15

\section{Wprowadzenie}

Pojęcie przedsiębiorczości akademickiej stało się w ostatnich latach bardzo popularne. Wynika to w dużej mierze ze zmieniającej się roli uniwersytetu, który stopniowo przekształca się w „uniwersytet trzeciej generacji”, w odróżnieniu od wcześniejszych uczelni średniowiecznych i humboldtowskich (Wissema, 2005). Współczesny uniwersytet, realizujac misję kształcenia i rozwoju, funkcjonuje także coraz bliżej realiów społeczno-gospodarczych. W warunkach gospodarki opartej na wiedzy (GOW) nauka staje się istotnym czynnikiem rozwoju gospodarczego, przyczyniając się do tworzenia innowacji, tworzenia przedsiębiorstw opartych na nowoczesnych technologiach, sprzyja zakładaniu firm przez studentów czy naukowców, a w rezultacie - rozwojowi konkurencyjności (Borges i Filion, 2013; Banerski i in., 2009).

\section{Przedsiębiorczość akademicka w świetle literatury przedmiotu}

Współczesne szkoły wyższe pełnią nie tylko dotychczasowe funkcje - kształcenia oraz realizowania badań. Nie są one bowiem, jak niegdyś, instytucjami odizolowanymi od otoczenia. Przeciwnie, aktualnie uczelnie są ściśle powiązane zarówno ze społecznością regionalną oraz krajową, jak i, coraz częściej, globalną. Te związki szkół wyższych z otoczeniem umożliwiają kształtowanie wartości dodanej, zdaniem badaczy - kluczowej w procesie przedsiębiorczości, z korzyścią nie tylko dla samych uczelni i środowiska akademickiego, lecz także dla rozwoju społeczno-gospodarczego (Svensson, Klofsten i Etzkowitz, 2012).

Coraz częściej szkoły wyższe zajmują się kształtowaniem postaw przedsiębiorczych studentów oraz pracowników, umożliwiając im samodzielne funkcjonowanie na rynku. Uczelnie stają się ośrodkami innowacji i rozwoju, a także miejscem powstawania nowych przedsiębiorstw. Przejawia się to w promowaniu współpracy z biznesem, zachęcaniu młodych ludzi do samozatrudnienia, a także wspieraniu rozwoju przedsiębiorczości prowadzącej do komercjalizacji wiedzy i wyników badań naukowych. W warunkach globalnej konkurencji w misję uniwersytetu przedsiębiorczego wpisane jest dążenie do wykorzystywania wyników badań w praktyce, a także - uzyskiwanie korzyści z tego typu działalności (Binkauskas, 2012).

Przedsiębiorcza misja współczesnego uniwersytetu jest konsekwencją oddziaływania szeregu czynników zewnętrznych. Do ważniejszych należy zaliczyć m.in. trudności z finansowaniem szkół wyższych (przy malejącym udziale ze środków budżetowych), co tym samym powoduje konieczność poszukiwania dodatkowego wsparcia finansowego $\mathrm{z}$ funduszy zewnętrznych. Kolejnym czynnikiem wpływającym na wzrost aktywności uczelni jest rozszerzająca się współpraca z przedstawicielami biznesu, w ramach której realizowane są wspólne projekty i konferencje; przedstawiciele firm uczestniczą w realizacji zajęć, prac dyplomowych i projektów (które zyskują tym samym wymiar praktyczny), zaś badania naukowe prowadzone są coraz częściej na zlecenie biznesu (Schulte i in., 2013; Howells i in., 2012). Otwieranie się uczelni na współpracę z biznesem, w celu wzmocnienia powiązań działalności badawczej z sektorem prywatnym znalazło się wśród zaleceń dla szkół wyższych, opracowanych w wyniku badań zrealizowanych w ramach Programu na rzecz Lokalnego Rozwoju Gospodarczego i Zatrudnienia (LEED) Organizacji Współpracy Gospodarczej i Rozwoju (Umiejętności i kompetencje..., 2013). Zdaniem autorów raportu bliższa 
współpraca szkół wyższych z biznesem ma na celu zintensyfikowanie działań związanych $\mathrm{z}$ przedsiębiorczością $\mathrm{w}$ uczelniach, a także kształtowanie pozytywnych postaw wobec przedsiębiorczości.

Rozwojowi przedsiębiorczości akademickiej sprzyjaja również korzystne czynniki wewnętrzne uczelni, m.in. dążenie do rozwoju i intensyfikowania wspólpracy z biznesem, a ponadto orientacja na nowoczesność i innowacje (Osiri i McCarty, 2013). Ważną rolę odgrywa autonomia szkoły wyższej, pozwalająca na kształtowanie kultury rozwoju oraz tworzenie klimatu innowacyjności. Sprzyjają temu ponadto elastyczność działania i umiejętność dostosowywania do nowego modelu bazującego na bliższej wspólpracy uczelni z biznesem (Shattock, 2005; Okoń-Horodyńska, 2008). Podejmowanie tego rodzaju aktywności wiąże się jednocześnie $\mathrm{z}$ koniecznością tworzenia odpowiednich warunków oraz rozwijaniem infrastruktury organizacyjnej i mechanizmów wspierających zaangażowanie młodych ludzi w działalność gospodarczą (takich jak centra transferu technologii, parki naukowe, centra innowacji, inkubatory przedsiębiorczości (Brennan i McGowan, 2005).

W literaturze przedmiotu pojawia się wiele definicji przedsiębiorczości akademickiej. Najczęściej jest ona rozumiana szeroko - jako przedsiębiorczość środowiska akademickiego, przejawiająca się w zaangażowaniu jednostek naukowych, ich pracowników, studentów, absolwentów i doktorantów w działalność gospodarcza (Guliński i Zasiadły, 2005). Jednocześnie podkreśla się, że przedsiębiorczość akademicka jest pojęciem złożonym, a decyzje szkół wyższych, dotyczące rozwijania tego typu strategii, wymagają uczestnictwa naukowców i studentów w projektach rozwoju przedsiębiorczości (Laukkanen, 2003).

\section{Kierunki rozwoju Lubelszczyzny}

Rozwój przedsiębiorczości akademickiej jest ważną determinantą rozwoju regionu. Lubelszczyzna, jako trzecie pod względem wielkości województwo Polski (pow. 25114 $\mathrm{km}^{2}$ ), mimo znacznych rozmiarów, należy wciąż do najbiedniejszych, a także najsłabiej zurbanizowanych oraz zaludnionych regionów w Polsce (Strategia Rozwoju..., 2010). Sytuację tę determinują w znacznej mierze: rolniczy charakter województwa, czynniki demograficzne (utrzymujący się od lat 90. XX w. spadek liczby ludności), a także niewielka liczba przedsiębiorstw. Przeprowadzone w 2011 r. badania Polskiej Agencji Rozwoju Przedsiębiorczości wskazują, że Lubelszczyzna znajduje sie na przedostatnim miejscu wśród polskich województw pod względem rozwoju przedsiębiorczości (Tarnawa i Zadura-Lichota, 2013). Wartość syntetycznego wskaźnika przedsiębiorczości regionu lubelskiego wyniosła 28,20, przy czym lider rankingu, Mazowsze, osiagną1 wartość niemal trzykrotnie wyższą - 83,081.

Siłę napędową rozwoju regionu lubelskiego stanowią jedynie przedsiębiorstwa mikro, małe i średnie. Województwo lubelskie plasuje się jednak na przedostatnim miejscu wśród polskich województw pod względem liczby MSP na 1000 mieszkańców Polski $(35,16$ przy średniej dla kraju 46,22) (Tarnawa i Zadura-Lichota, 2013). Lubelskie przedsiębiorstwa odznaczają się także niskimi na tle kraju nakładami na działalność innowacyjną. W 2013 r. wkład sektora lubelskich przedsiębiorstw w działalność innowacyjna wyniósł 19,2\% całości nakładów (wobec 37,3\% średnio w kraju), zaś sektora rządowego - 69,3\% (47,3\% w kraju). Z kolei nakłady na działalność innowacyjną $\mathrm{w}$ przemyśle wyniosły $2,3 \%$ ogółu nakładów w kraju, w tym zaledwie $0,18 \%$ wykorzystano na działalność badawczo-rozwojowa (Dmochowska, 2015).

W odniesieniu do potrzeb rozwojowych regionu dokumenty programowe województwa (Strategia Rozwoju Województwa Lubelskiego na lata 2006-2020, Regionalna Strategia Innowacji Województwa Lubelskiego do 2020 roku, Regionalny Program Operacyjny Województwa Lubelskiego) przewidują wspieranie rozwoju przedsiębiorczości. Wsparcie ma w szczególności dotyczyć rozwoju sektora mikro, małych i średnich przedsiębiorstw. W perspektywie finansowej 2014-2020 Regionalny Program Operacyjny Województwa Lubelskiego obejmuje przede wszystkim działania zwiększające konkurencyjność przedsiębiorstw, oraz wzmacniające regionalne inteligentne specjalizacje, w szczególności w zakresie innowacji oraz prac badawczo-rozwojowych.

Rozwój nowoczesnych technologii oraz innowacyjności przedsiębiorstw powinien angażować akademicki potencjał Lubelszczyzny (Buczacki, 2008). W województwie funkcjonuje bowiem 18 szkół wyższych, które zatrudniają wykwalifikowaną kadrę, kształcącą studentów w wielu kierun- 
kach, w tym także szczególnie istotnych dla rozwoju regionu. Program Operacyjny Inteligentny Rozwój 2014-2020 zakłada wybór przez poszczególne regiony tzw. inteligentnych specjalizacji, których celem jest optymalne wykorzystanie potencjału poszczególnych regionów. Istotne jest także dopasowanie kierunków przyszłego rozwoju do specyficznych uwarunkowań społeczno-gospodarczych. Szczególne znaczenie ma tu dopasowanie współpracy na płaszczyźnie nauka-edukacja-gospodarka. W regionie lubelskim zdiagnozowano cztery inteligentne specjalizacje, takie jak: biogospodarka, usługi medyczne i prozdrowotne, informatyka i automatyka oraz energetyka niskoemisyjna. W najbliższych latach na wsparcie w ramach funduszy unijnych będą mogły liczyć przede wszystkim przedsiębiorstwa działające $\mathrm{w}$ jednej z czterech inteligentnych specjalizacji Lubelszczyzny.

Istotnym problemem Lubelszczyzny, wpływającym w sposób negatywny na rozwój regionu, jest także wysoki poziom bezrobocia. Stopa bezrobocia rejestrowanego w 2013 r. wyniosła 14,4\% ogółu ludności aktywnej zawodowo (wobec 13,4\% średnio w kraju). Niepokojącym zjawiskiem jest utrzymujacy się znaczny poziom bezrobocia wśród osób młodych. W roku 2013 co trzecia osoba bezrobotna była w wielu 25-34 lata, a niemal połowa bezrobotnych $(48,4 \%)$ była w wieku tzw. najwyższej mobilności zawodowej (do 44 lat). Wskaźnik bezrobocia rejestrowanego wśród osób z wykształceniem wyższym wyniósł $15,1 \%$ (12\% w kraju) (Dmochowska, 2015).

Tak wysoki wskaźnik bezrobocia wśród młodych osób, często dobrze wykształconych, powoduje odpływ potencjalnego kapitału ludzkiego poza Lubelszczyznę. Chcąc przeciwdziałać tym niekorzystnym trendom, władze regionu poszukuja pomysłów na zachęcenie młodych ludzi do pozostawania w województwie. Jedną z możliwości wydaje się zachęcanie młodych ludzi do samozatrudnienia, wspierania rozwoju przedsiębiorczości akademickiej oraz bliższej współpracy instytucji badawczo-naukowych z biznesem (Jakubiak i Mażewska, 2014).

\section{Metodyka badań empirycznych}

Materiał empiryczny stanowią wyniki badań, będące częścią większego projektu zrealizowanego na zlecenie Urzędu Marszałkowskiego Województwa Lubelskiego
- Regionalny System Zarzadzania Zmiana Gospodarcza.

Badania zrealizowano w 2014 roku metodą sondażu z wykorzystaniem kwestionariusza ankiety. Badaniami objęto reprezentatywną grupę 390 studentów uczelni publicznych województwa lubelskiego. Respondenci byli studentami ostatnich lat studiów magisterskich na kierunkach związanych $\mathrm{z}$ dziedzinami inteligentnych specjalizacji województwa lubelskiego. Pod względem liczebności próby dominowali studenci Politechniki Lubelskiej (PL; 36\%). Co czwarty badany studiował na Uniwersytecie Marii Curie-Skłodowskiej (UMCS). Pozostałe lubelskie uczelnie prezentowane były mniej licznie (rysunek 1 ). W strukturze badanych nieznaczną przewagę stanowiły kobiety $(58 \%)$.

Rysunek 1. Reprezentowane przez badanych uczelnie $(\%, n=390)$

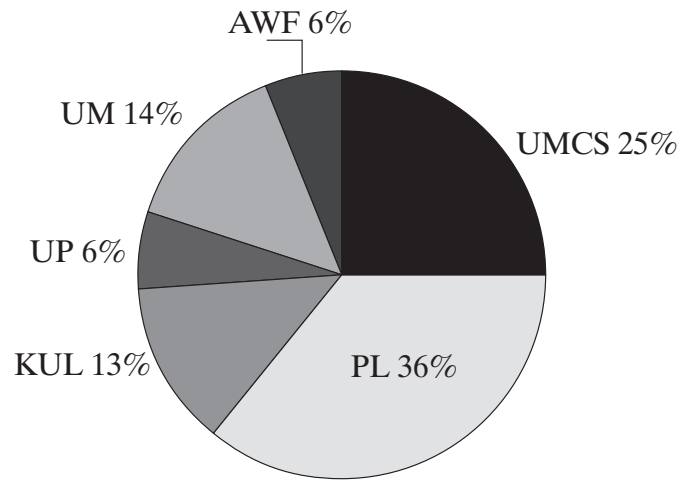

Objaśnienia: UMCS - Uniwersytet Marii Curie-Skłodowskiej w Lublinie, PL - Politechnika Lubelska, KUL - Katolicki Uniwerstet Lubelski Jana Pawła II, UP - Uniwersytet Przyrodniczy w Lublinie, UM - Uniwersytet Medyczny, AWF - Akademia Wychowania Ficzycznego w Warszawie, Filia w Białej Podlaskiej

Źródło: opracowanie własne na podstawie badań ankietowych.

Charakterystykę badanych pod względem kierunków studiów przedstawia tabela 1. Należy podkreślić, że struktura studentów reprezentujących poszczególne kierunki studiów (biorących udział w badaniu) była proporcjonalna do liczby osób studiujących na tych kierunkach w województwie lubelskim. Największa grupa $-41 \%$ respondentów studiowała na kierunkach społecznych, co piąty - medycznych, podobny odsetek na kierunkach inżynieryjnych. Najmniej licznie reprezentowano kierunki biologiczne oraz związane z ochroną środowiska (po 3\% badanych). 
Tabela 1. Kierunki studiów reprezentowane przez badanych (\%, $n=390)$

\begin{tabular}{|c|l|c|}
\hline Lp. & Grupa kierunków wg GUS & \% \\
\hline 1. & inżynieryjne & 19 \\
\hline 2. & społeczne & 41 \\
\hline 3. & biologiczne & 3 \\
\hline 4. & rolno-weterynaryjne & 6 \\
\hline 5. & medyczne & 20 \\
\hline 6. & matematyczne & 5 \\
\hline 7. & informatyczne & 4 \\
\hline 8. & ochrona środowiska & 3 \\
\hline
\end{tabular}

Źródło: opracowanie własne na podstawie badań ankietowych.

\section{Plany badanych w zakresie przedsiębiorczości}

Badani, kończąc studia II stopnia, powinni prezentować określony poziom kompetencji przedsiębiorczych. Istotne było zatem ustalenie ich postaw w tym zakresie. Na pytanie odnośnie do planów założenia własnej działalności gospodarczej największa grupa badanych (44\%) udzieliła odpowiedzi twierdzacej. Zbliżony odsetek $(39 \%)$ nie miał jeszcze sprecyzowanych planów w tym zakresie, a jedynie $15 \%$ nie miało takich zamiarów. Zaledwie co pięćdziesiąty badany był właścicielem firmy w momencie realizacji badań (rysunek 2).

Rysunek 2. Deklaracje respondentów odnośnie do założenia własnej działalności

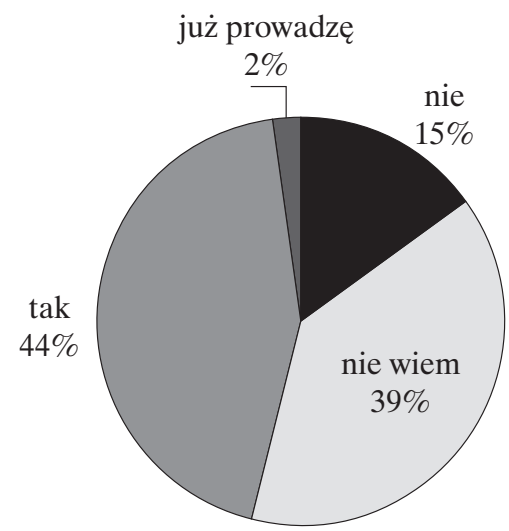

Źródło: opracowanie własne na podstawie badań ankietowych.
Podjęta próba oceny, czy deklaracje respondentów uzależnione są od charakteryzujących ich zmiennych społeczno-demograficznych, pokazała różnice istotne statystycznie jedynie w przypadku płci. Badani mężczyźni częściej niż ich koleżanki ze studiów deklarowali założenie własnej firmy w przyszłości $\left(55 \%\right.$ vs. $39 \% ; \chi^{2}=9,91$, $\mathrm{df}=2$ ).

Interesujące dla autorów było także ustalenie perspektywy czasowej dotyczącej planów podjęcia przez respondentów własnej działalności (rysunek 3). Blisko połowa badanych (47\%) deklarowała, że będzie to czas dłuższy niż 2 lata, a dalsze $39 \%$ nie miało sprecyzowanych planów. Znacznie mniej respondentów planowało założenie firmy w krótszym czasie (poniżej roku $2 \%$, zaś w okresie 1-2 lat-12\%).

Rysunek 3. Pespektywa czasowa założenia własnej działalności

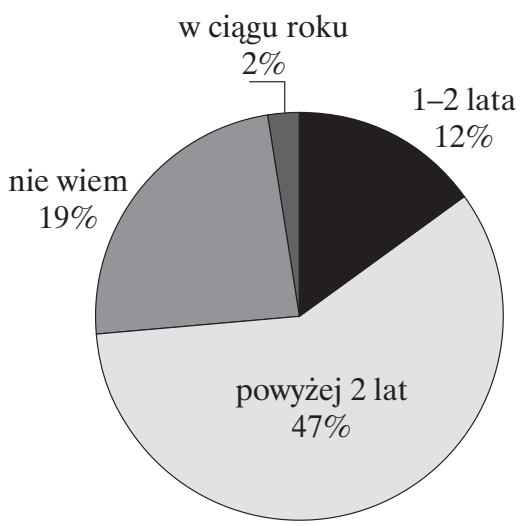

Źródło: opracowanie własne na podstawie badań ankietowych.

Także w przypadku planów związanych z perspektywą założenia firmy kobiety okazały się mniej zdecydowane niż mężczyźni, cześsiej udzielajac odpowiedzi „nie wiem” $\left(49 \%\right.$ vs $25 \%$ - méżczyźni; $\chi^{2}=23$, df $\left.=2\right)$. Z kolei mężczyźni częściej deklarowali założenie działalności w perspektywie do 2 lat od ukończenia studiów (22\% vs $8 \%$; $\chi^{2}=23, \mathrm{df}=2$ ).

Zapytani o motywy podjęcia działalności gospodarczej respondenci najczęściej odpowiadali, że własna firma umożliwi im realizację planów życiowych, rozwój, samorealizację. Takie deklaracje złożyła niemal co trzecia osoba planująca założyć firmę. Co czwarty badany wskazał, że prowadzenie własnej działalności umożliwi mu zarobie- 
nie większych pieniędzy, niż w przypadku pracy etatowej.

Z kolei osoby, które nie zamierzały prowadzić własnej firmy najczęściej uzasadniały swoją decyzję brakiem środków na jej uruchomienie bądź wiązały swoje deklaracje z ewentualnym ryzykiem niepowodzenia (w przypadku obu dopowiedzi co piąty z tej grupy respondentów).

\section{Opinie badanych odnośnie do prowadzenia firmy}

Respondenci, niezależnie od deklaracji dotyczącej prowadzenia własnej firmy, zostali poproszeni o dokonanie oceny konsekwencji jej posiadania (rysunek 4). Do pozytywnych skutków badani zaliczyli możliwość rozwoju własnych umiejętności i zdolności (89\%), zadowolenie i satysfakcję (88\%), możliwość większego (niż w przypadku pracy etatowej) zarobku
(86\%), a także prestiż (76\%). Z kolei wśród negatywnych konsekwencji prowadzenia firmy wymieniano stres (91\%), ograniczenie wolnego czasu $(78 \%)$ oraz ryzyko straty (75\%).

Respondenci wskazywali także swoje obawy związane z prowadzeniem firmy. Wśród nich wymieniano najczęściej dużą biurokrację ( $87 \%)$, wysokie koszty prowadzenia i brak funduszy na rozpoczęcie działalności (po 78\%), częste zmiany przepisów $(75 \%)$ i ogólnie złą sytuację ekonomiczną w Polsce (70\%). Ponad polowa respondentów wskazała także, że obawia się braku wystarczającej wiedzy dotyczącej prowadzenia firmy (rysunek 5).

\section{Zakończenie}

Celem podjętych badań było zdiagnozowanie postaw przedsiębiorczych studentów wybranych uczelni lubelskich. Przedsię-

Rysunek 4. Odpowiedzi badanych na pytanie: „Co daje własna firma?” ( $n=390, \%)$

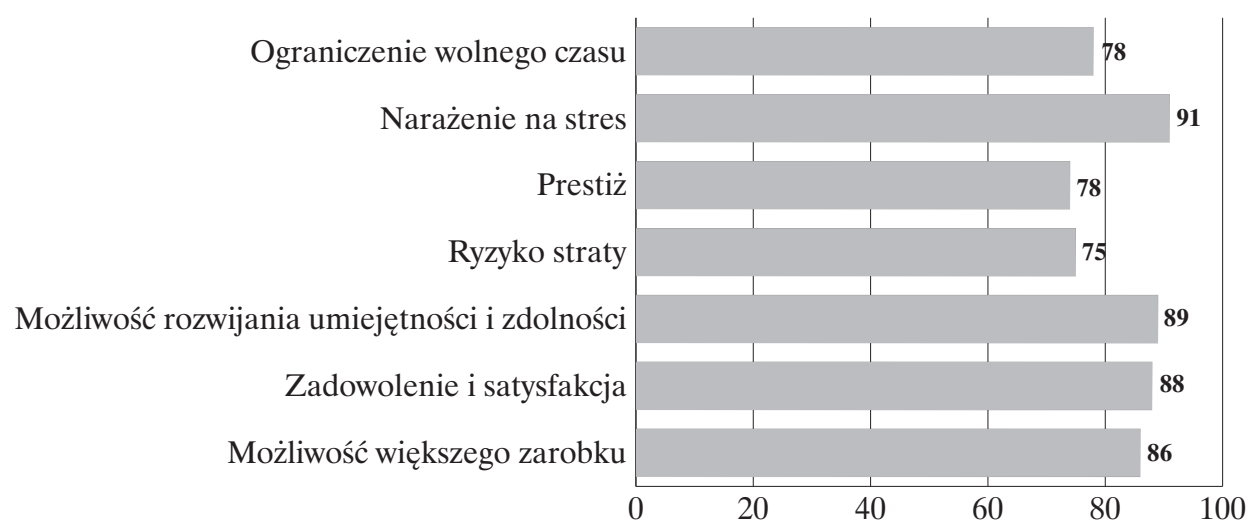

Źródło: opracowanie własne na podstawie badań ankietowych.

Rysunek 5. Odpowiedzi badanych na pytanie dotyczące obaw związanych z prowadzeniem firmy $(n=390, \%)$

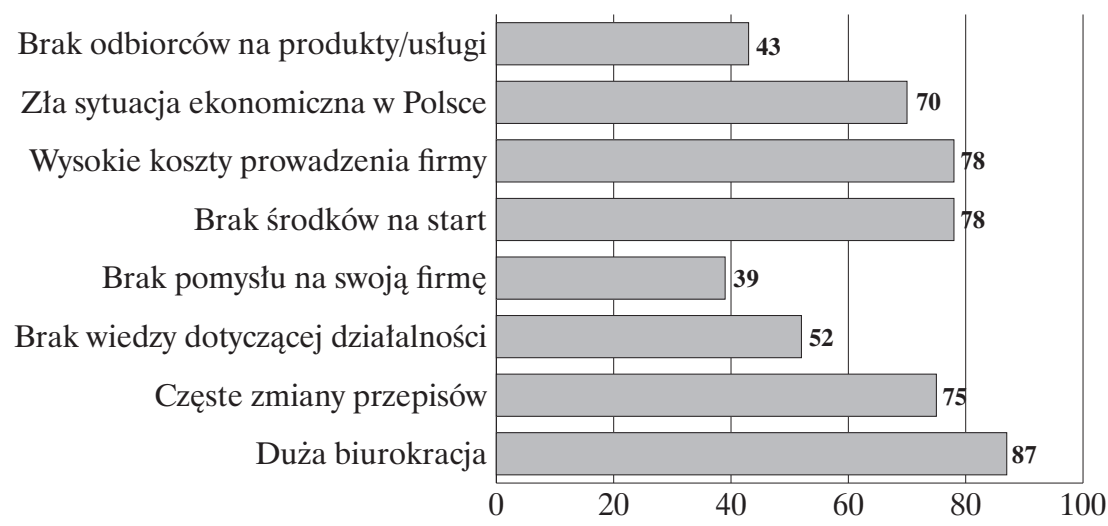

Źródło: opracowanie własne na podstawie badań ankietowych. 
biorczość jest bowiem uważana za jeden z trzech, obok innowacyjności i kreatywności, filarów gospodarki opartej na wiedzy. Przyjęto, że prezentowane postawy proprzedsiębiorcze badanych studentów moga rzutować na dalsze wybory zawodowe absolwentów, a w konsekwencji oddziaływać na przyszłość regionu.

Poszukując odpowiedzi na pytanie o determinanty postaw przedsiębiorczych wśród studentów lubelskich uczelni, przeprowadzono badania ankietowe. Objęto nimi osoby studiujace na kierunkach zaliczanych do obszarów inteligentnych specjalizacji Lubelszczyzny.

Analiza wyników przeprowadzonych badań wykazała, że jedynie $44 \%$ badanych zadeklarowało podjęcie w przyszłości własnej działalności gospodarczej. Tymczasem sytuacja gospodarcza województwa lubelskiego nie wskazuje, aby pozostały odsetek absolwentów badanych kierunków studiów miał szansę znalezienia satysfakcjonującej pracy w regionie.

Wśród deklarowanych ograniczeń prowadzenia firmy najczęściej pojawiały się brak środków na uruchomienie działalności oraz lęk przed niepowodzeniem. Nie była to jednak jedyna obawa respondentów związana $\mathrm{z}$ podjęciem własnej działalności. Większość badanych wymieniła wiele negatywnych aspektów prowadzenia firmy, w tym dużą biurokrację, wysokie koszty prowadzenia i brak funduszy, częste zmiany przepisów i ogólnie złą sytuację ekonomiczna w Polsce. Podobne przyczyny utrudniające prowadzenie działalności gospodarczej wskazywali w zrealizowanym w $2011 \mathrm{r}$. badaniu krakowscy studenci, podkreślając najczęściej ciągle zmieniające się przepisy prawne oraz rozbudowaną biurokrację. Istotną barierę stanowit, ich zdaniem, także brak środków finansowych zarówno na rozpoczęcie, jak i na prowadzenie działalności gospodarczej (Marszałek, 2012).

W kontekście podjętej problematyki niepokojące wydaje się ustalenie, że ponad połowa respondentów prezentowanych badań zadeklarowała brak wystarczającej wiedzy dotyczącej prowadzenia działalności gospodarczej. Tendencje te korespondują z ustaleniami wcześniejszych badań zrealizowanych przez Wojewódzki Urząd Pracy w Lublinie, z których wynika m.in., że „system edukacji nie w pełni sprzyja rozwojowi kreatywności, kompetencji miękkich, samodzielności, a więc cech przesądza- jących w znacznym stopniu o możliwości łagodnego dostosowania się do aktualnych wymogów rynku (...). System edukacji zawodowej na Lubelszczyźnie, zarówno na poziomie ponadgimnazjalnym, jak i wyższym, nie spełnia wymogów współczesnej gospodarki w zakresie kształcenia praktycznego i rozwijania kompetencji" (Perspektywy ludzi młodych..., 2011). Tymczasem do kształtowania kompetencji przedsiębiorczych studentów zobowiązuja szkoły wyższe założenia zawarte w Krajowych Ramach Kwalifikacji oraz zalecenia OECD. Tego typu działania wiążą się także z nową misją innowacyjnego uniwersytetu. Aktualnie plany i programy studiów powinny być podporządkowane ukształtowaniu określonej przez uczelnię sylwetki absolwenta, w której istotny wymiar stanowią kompetencje przedsiębiorcze. W przypadku kierunków studiów wpisujących się $w$ inteligentne specjalizacje regionu wydaje się to szczególnie ważne. Z tego względu szkoły wyższe powinny dołożyć wszelkich starań, aby w programach określonych przedmiotów znalazło się miejsce na zagadnienia formujące postawy przedsiębiorcze. Należy przy tym podkreślić, że przedsiębiorczość nie jest sumą wiedzy, lecz raczej funkcją kompetencji i określonych postaw. Przedsiębiorczość, zdaniem badaczy, to proces, mający motywować jednostki do tworzenia wartości dodanej, poszukiwania pomysłów, rozpoznawania szans i podejmowania ryzyka (Oleksyn, 2006).

Sygnalizowane przez badanych studentów obawy związane $\mathrm{z}$ prowadzeniem firmy pokazują, że wielu z nich ma dość stereotypowy pogląd na biznes. Jawi się on jako coś bardzo ryzykownego, obarczonego wieloma negatywnymi konsekwencjami. Oczywiście nie znaczy to, że tego typu skutki nie mogą się pojawić. Czynnik ryzyka jest bowiem nieodłączną cechą działalności przedsiębiorcy; nie ma przedsiębiorczości wolnej od ryzyka. Istnieje jednak także wiele pozytywnych aspektów prowadzenia firmy i te należy pokazywać młodzieży. W tym celu szkoły wyższe powinny zintensyfikować współpracę $\mathrm{z}$ biznesem, a także instytucjami otoczenia biznesu. Funkcjonujące w tym zakresie stowarzyszenia, fundacje, klastry (w samym województwie lubelskim jest ich ok. pięćdziesiąt) działają na rzecz wspierania przedsiębiorców, prowadząc doradztwo i szkolenia, a także pomagając w pozyskiwaniu środków na uruchomienie 
i prowadzenie działalności. Istotną rolę powinny tu także odgrywać funkcjonujące przy większości uczelni Akademickie Inkubatory Przedsiębiorczości i biura karier. Jednostki tego typu prowadzą działania obejmujące m.in. wspieranie i popularyzację idei przedsiębiorczości w środowisku akademickim, a także udzielają różnorodnej pomocy początkującym przedsiębiorcom (m.in. poprzez realizację projektów, szkoleń, doradztwa).

Dokładniejsza analiza wyników przeprowadzonych badań pokazała, że czynnikiem różnicującym opinie badanych jest płeć. Mężczyźni częściej niż ich koleżanki, deklarowali chęć założenia firmy, byli także częściej zdecydowani w kwestii określenia perspektywy czasowej założenia firmy. Jest to prawdopodobnie konsekwencja funkcjonujących w społeczeństwie stereotypów ról płciowych. Działania szkół wyższych powinny być więc skoncentrowane na rozwijaniu kompetencji przedsiębiorczych wśród przedstawicieli obu płci. Wydaje się, że szczególnego wsparcia oczekują w tym względzie kobiety, co mogłoby zwiększyć ich wiarę we własne siły i możliwość osiagnnięcia sukcesu $\mathrm{w}$ roli przedsiębiorcy. Istotne byłoby pokazywanie przykładów karier kobiet, które odniosły sukces na polu zarówno zawodowym, jak i życiowym.

Organizacja szkoleń lub doradztwa przygotowujących do zakładania i prowadzenia własnej firmy nie powinna być jedynie zadaniem uczelni. Podczas zajęć uczelnianych można bowiem zrealizować jedynie pewne elementy programu przedsiębiorczości. Warto natomiast zachęcać studentów do korzystania także z usług pozauczelnianych instytucji otoczenia biznesu (IOB). Jest to tym bardziej wskazane, że co drugi respondent deklarował brak wystarczającej wiedzy z zakresu prowadzenia działalności gospodarczej.

Ważne wydaje się, że badani widzą szereg pozytywnych aspektów prowadzenia własnej działalności gospodarczej. Respondenci podkreślali, że umożliwia ona rozwój zainteresowań i umiejętności, daje zadowolenie i satysfakcję oraz pozwala osiagnnąć większe zarobki. Także w tym obszarze wyniki badań potwierdzają badania zrealizowane wśród studentów polskich uczelni. Jako motywy zakładania i prowadzenia własnej działalności wskazywali oni najczęściej chęć osiągnięcia większych korzyści finansowych, stabilność finansową oraz możliwość stworzenia sobie miejsca pracy (Marszałek, 2012; Jelonek, 2011).

W wyniku analiz ustalono, że deklarowanych przez badanych postaw przedsiębiorczych nie różnicował ani kierunek studiów, ani typ uczelni, ani podejmowanie podczas studiów prac zawodowych. Może to wynikać z faktu, że badani, studiując w trybie stacjonarnym, podejmowali jedynie dorywcze, niekoniecznie powiązane $\mathrm{z}$ wyuczonym zawodem zajęcia.

Wyniki przeprowadzonych badań potwierdzaja ustalenia Bilansu Kapitału Ludzkiego. Jak wynika z badań zrealizowanych przez Polska Agencję Rozwoju Przedsiębiorczości (PARP) we współpracy z Uniwersytetem Jagiellońskim (UJ), własny biznes staje się coraz atrakcyjniejszą alternatywą dla etatu (odpowiedziało tak 39\% spośród ponad 33 tys. badanych studentów polskich uczelni) (Jelonek, 2011). Podobne wyniki osiagnnięto w badaniach zrealizowanych w 2011 r. wśród 221 studentów krakowskich szkół wyższych. $39 \%$ spośród badanych studentów zadeklarowało wówczas, że rozważa założenie w przyszłości własnej firmy (Marszałek, 2012). Jak wynika z badań PARP i UJ, polscy studenci coraz bardziej skłonni są założyć własną firmę po ukończeniu studiów, przy czym częściej dotyczy to mężczyzn niż kobiet. $\mathrm{Z}$ badań wynika, że więcej badanych rozważało możliwość zostania przedsiębiorca, niż wybierało tę formę zatrudnienia jako najbardziej atrakcyjną. Założenie biznesu może być więc rozpatrywane jako alternatywna do etatu forma zdobycia pracy. Jest to szczególnie istotne w przypadku Lubelszczyzny, będącej regionem o wysokim wskaźniku bezrobocia wśród ludzi młodych.

\section{Przypisy}

1 Wskaźnik syntetyczny rozwoju przedsiębiorczości uwzględnia m.in. liczbę przedsiębiorstw, liczbę osób pracujących w przedsiębiorstwach, a także wielkości przychodów, kosztów oraz nakładów inwestycyjnych.

\section{Bibliografia}

Banerski, G., Gryzik, A., Matusiak, K.B., Mażewska, M. i Stawasz, E. (2009). Przedsiębiorczość akademicka. Raport z badania. Warszawa: Polska Agencja Rozwoju Przedsiębiorczości.

Binkauskas, G. (2012). Academic entrepreneurship: Barriers and fears versus wishes and opportunities. International Journal of Technology Management \& Sustainable Development. 11(3), 231-244. 
Borges, C. i Filion, L.J. (2013). Spin-off Process and the Development of Academic Entrepreneur's Social Capital. Journal of Technology, Management \& Innovation, 8(1), 21-34.

Buczacki, A. (2008). Regionalna Strategia Innowacji Województwa Lubelskiego na lata 2008-2015. Lublin: Oficyna Wydawnicza Politechniki Lubelskiej.

Dmochowska, H. (red.) (2015). Rocznik Statystyczny województw 2014. Warszawa: Główny Urząd Statystyczny.

Giedrojć, K., Zaręba, J. i Gajewski Z. (2012). Przedsiębiorcy w Polsce. Fakty, liczby, przyktady. Warszawa: Polska Konfederacja Przedsiębiorców Prywatnych Lewiatan.

Guliński, J. i Zasiadły, P. (red.) (2005). Innowacyjna przedsiębiorczość akademicka - światowe doświadczenia. Warszawa: Polska Agencja Rozwoju Przedsiębiorczości.

Howells, J., Ramlogan, R. i Cheng, S.L. (2012). Innovation and university collaboration: paradox and complexity within the knowledge economy. Cambridge Journal of Economics, 36(3), 703-721.

Jakubiak, M. i Mażewska, M. (2014). Analiza możliwości wdrożenia międzyuczelnianego programu inkubowania i rozwoju innowacyjnych firm $w$ branzach inteligentnych specjalizacji województwa lubelskiego. Lublin: Urząd Marszałkowski Województwa Lubelskiego.

Jelonek, M. (2011). Raport z badań studentów i analizy kierunków kształcenia realizowanych w $2010 \mathrm{r}$. w ramach projektu „Bilans Kapitału Ludzkiego”. Studenci - przyszłe kadry polskiej gospodarki. Warszawa: Polska Agencja Rozwoju Przedsiębiorczości.

Marszałek, A. (2012). Analiza postaw przedsiębiorczych wśród studentów. E-mentor, 3(45), 25-34.

Okoń-Horodyńska, E. (2008). Edukacja dla innowacji (czy tylko wybrani skazani są na sukces innowacyjny?). Nauka i Szkolnictwo Wyższe, 1(31), 34-54.
Oleksyn, T. (2006). Zarzadzanie kompetencjami. Teoria i praktyka. Kraków: Oficyna Ekonomiczna.

Perspektywy ludzi mtodych na rynku pracy. (2011). Lublin: Wojewódzki Urząd Pracy.

Schulte, P. i in. (2013). Resita network - academic entrepreneurship and innovation network of South Eastern European universities: an example of successful networking in entrepreneurship and innovation at academic level. Serbian Journal of Management, 8(1): 117-130.

Strategia Rozwoju Województwa Lubelskiego na lata 2006-2020. Raport monitoringowy za rok 2010. Pozyskano z: http://www.lubelskie.pl/img/userfiles/ files/Rozwoj_regionalny/Raport_Monitoringowy_ SRWL_za_rok_2010.pdf

Svensson, P., Klofsten, M. i Etzkowitz, H. (2012). An entrepreneurial university strategy for renewing a declining industrial city: The Norrkoping way. European Planning Studies, 20(4), 505-525.

Tarnawa, A. i Zadura-Lichota, P. (2013). Raport o stanie sektora matych $i$ średnich przedsiębiorstw $w$ Polsce $w$ latach 2011-2012. Warszawa: Polska Agencja Rozwoju Przedsiębiorczości.

Umiejętności i kompetencje $w$ zakresie przedsiębiorczości (2013). Raport dot. Polski z badania zrealizowanego w ramach Programu na rzecz Lokalnego Rozwoju Gospodarczego i Zatrudnienia (LEED) Organizacji Współpracy Gospodarczej i Rozwoju (OECD). Warszawa: Ministerstwo Infrastruktury i Rozwoju. Pozyskano z: http://www.fundusze. uj.edu.pl/documents/31275205/603827e5-63e6451c-9f78-608697ade8dc

Wissema, J.G. (2005). Technostarterzy - dlaczego i jak? Warszawa: Polska Agencja Rozwoju Przedsiębiorczości.

http://rszzg.lubelskie.pl/

http://www.rsi.lubelskie.pl

http://www.stat.gov.pl

https://www.poir.gov.pl/ 